\title{
Contrasting molecular diversity and demography patterns in two intertidal amphipod crustaceans reflect Atlantification of High Arctic
}

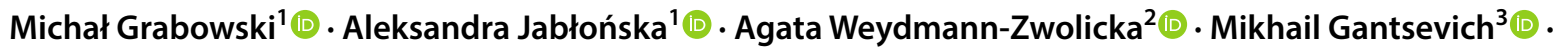 \\ Petr Strelkov ${ }^{4}\left[\right.$. Maria Skazina ${ }^{4}$ (D) Jan Marcin Węsławski ${ }^{5}[$
}

Received: 7 February 2019 / Accepted: 1 October 2019 / Published online: 11 November 2019

(c) The Author(s) 2019

\begin{abstract}
The distribution of two common intertidal amphipod species Gammarus oceanicus and Gammarus setosus was studied along the coast of Svalbard Archipelago. Genetic analysis showed geographical homogeneity of G. oceanicus with only one molecular operational taxonomic unit (MOTU) and much higher diversification of G. setosus (5 MOTUs) in the studied area. Only two MOTUs of G. setosus are widespread along the whole studied Svalbard coastline, whereas the remaining three MOTUs are present mainly along the northern and eastern parts of archipelago's largest island, Spitsbergen. Distribution analysis indicates that the demographic and spatial expansion of G. oceanicus in the northern Atlantic has started already during the Last Glacial Maximum (LGM, ca. 18 ka), while G. setosus seems to be a long-persistent inhabitant of the Arctic, possibly even through the LGM, with slower distribution dynamics. Combining the results of our molecular study with previous field observations and the knowledge upon the direction of ocean currents around the Svalbard Archipelago, it can be assumed that G. oceanicus is a typical boreal Atlantic species that is still continuing its postglacial expansion northwards. In recent decades it colonized High Arctic due to the climate warming and has partly displaced G. setosus, that used to be the only common gammarid of the Svalbard intertidal zone.
\end{abstract}

Responsible Editor: E. Briski.

Reviewed by Undisclosed experts.

Electronic supplementary material The online version of this article (https://doi.org/10.1007/s00227-019-3603-4) contains supplementary material, which is available to authorized users.

Aleksandra Jabłońska

aleksandra.jablonska@biol.uni.lodz.pl

1 Department of Invertebrate Zoology and Hydrobiology, University of Lodz, Banacha 12/16, 90-237 Lodz, Poland

2 Institute of Oceanography, University of Gdansk, al. Marszałka Piłsudskiego 46, 81-378 Gdynia, Poland

3 Department of Invertebrate Zoology, Faculty of Biology, Moscow State University, Leninskie Gory 1, Build. 12, Moscow, Russia 119234

4 St. Petersburg State University, Universitetskaya Emb. 7/9, St. Petersburg, Russia 199034

5 Institute of Oceanology, Polish Academy of Sciences, Powstańców Warszawy 55, 81-712 Sopot, Poland

\section{Introduction}

The Arctic has been warming at a rate about three times faster than the global mean (IPCC 2014). This results in the melting of glaciers at large spatial scale as well as in the reduction of the duration, area and thickness of sea ice, including both fast ice on the coast and the drifting pack ice (ACIA 2005; Stroeve et al. 2012). Changes in the average air temperature are accompanied by the rise of ocean temperatures and increased northward transport of relatively warm Atlantic waters with the West Spitsbergen Current. These warm waters penetrate more northern parts of the European Arctic (Walczowski et al. 2012), intensifying the recently observed changes in the environment. All of the above described processes are sometimes called the "Atlantification" of the Arctic (Polyakov et al. 2017).

The increasing intrusion of Atlantic waters into the Arctic, consequently changes the distribution ranges of both the Atlantic and the Arctic species (Greene et al. 2008). The northward distribution shifts have been observed at all trophic levels, including bloom-forming coccolithophores (Neukermans et al. 2018), zooplankton (Beaugrand et al. 2002; Weydmann et al. 2014), and benthic mollusks (Berge 
et al. 2005). The success of arriving species depends on whether they are able to survive in the new environment. Nonetheless, the so far observed changes in the distribution shifts have moved up to several degrees north from their former occurrence ranges (Beaugrand et al. 2002; Neukermans et al. 2018). In consequence, this may lead to the reorganization of both marine and terrestrial ecosystems of the Arctic (Stempniewicz et al. 2007; Węsławski et al. 2009; Vihtakari et al. 2018).

Arrival of new species, reappearance of the former inhabitants from the last climate optimum (7000-4000 years ago) and range expansions of boreal species from the Norwegian Sea shelf have been observed also in Svalbard waters (Blacker 1957; Hopkins 2002; Berge et al. 2005; Fleischer et al. 2007; Beuchel and Gulliksen 2008; Węsławski et al. 2018). The warming of the Arctic and disappearance of land-fast ice, together with intensified erosion of the shores and coastal water turbidity, is responsible for the structural changes in the rocky-bottom and intertidal faunal communities. The most obvious are extreme fluctuations of salinity and temperature, as well as the devastating disturbance caused by scouring of land-fast ice.

Marine and brackishwater amphipods, particularly gammarids, due to their usually high abundance and biomass, combined with predominantly detritivorous feeding, are among keystone organisms maintaining the high rate of energy transfer in the intertidal ecosystems of the temperate and boreal climatic zones (Gerhardt et al. 2011). However, in contrast to their ecological importance, the genetic diversity, population structure and demography of these organisms have been still insufficiently studied. In comparison, high cryptic diversity, well pronounced spatial population genetic structuring and local endemism have been observed in several freshwater gammarids, particularly those with large distribution ranges (e.g. Mamos et al. 2016; CopilaşCiocianu and Petrusek 2017; Grabowski et al. 2017). Even the few published studies upon the marine taxa revealed that divergent cryptic lineages or even haplogroups may differ by geographical distributions, various habitats requirements, altitudinal and depth ranges, demographic histories or tolerance to environmental factors (Krebes et al. 2011; Hupało et al. 2018). In addition, a more general pattern of higher degree of genetic differentiation in non-invasive versus invasive gammarids was recently suggested (Baltazar-Soares et al. 2017). This underlines the importance of historical factors for the present composition and dynamics of benthic communities. Thus, the general scarcity of such studies upon the marine coastal gammarids is surprising, particularly in areas undergoing fast environmental changes, such as the High Arctic.

Two amphipod species, Gammarus oceanicus Segerstråle, 1947 and Gammarus setosus Dementieva, 1931, dominate intertidal fauna around the whole Svalbard Archipelago.
Both occur at localities covered with loose stones and rocks, reaching highest densities up to $2000 \mathrm{ind} / \mathrm{m}^{2}$, just below the mean low water mark (Węsławski 1994; Ikko and Lyubina 2010). They prefer moderately to low exposed sites, where large loose stones serve as a shelter against birds during low tide. According to Węsławski (1994), each of them seems to be very tolerant to changes in salinity ( 0 to 35 PSU) and temperature $\left(-1.5\right.$ to $8{ }^{\circ} \mathrm{C}$ on Spitsbergen). Both species are typical inhabitants of coastal marine and brackish waters in the North Atlantic with very similar reproductive potentials and wide, largely sympatric, distribution areas. Gammarus oceanicus ranges from Long Island on the eastern coast of North America, through the Arctic, to the southern North Sea and the Baltic Seas, while G. setosus ranges from the Bay of Fundy on the Atlantic coast of North America, to the Arctic (Steele and Steele 1970, 1972; Lincoln 1979; Węsławski 1983, 1991; Gaston and Spicer 2001). Recent molecular studies have suggested presence of geographic structuring in both species, with diversified populations and even divergent lineages along the boreal North American coast versus the Arctic and boreal European coastlines (Costa et al. 2009; Krebes et al. 2011).

Although the habitat preferences of both littoral Gammarus species are very similar elsewhere (Tzvetkova 1975; Steele and Steele 1975; Węsławski 1994), the Arctic G. setosus is expected to perform better in lower temperature, while boreal G. oceanicus in warmer conditions (Steele and Steele 1970, 1972, 1974; Whiteley et al. 2011). Large scale comparison of Gammarus species occurrence in Svalbard was done between 1980-1994 and 2008-2016 (Węsławski et al. 2018). It shows that G. oceanicus has apparently expanded its distribution range along the west and north coasts of Spitsbergen and has increased its dominance on the expense of G. setosus, which has generally remained where it was observed 20 years ago.

In the present paper, we aim to reveal whether the observed extension of distribution range and increasing domination of G. oceanicus in Svalbard versus the generally decreasing abundance of $G$. setosus is reflected in genetic diversity of the local populations of both species. We hypothesised that $G$. oceanicus, that is presumably a recent newcomer to the High Arctic, would be characterised by rather uniform population genetic structure, without a clear spatial pattern, yet with strong signal of recent demographic and spatial expansion. In contrast, the populations of G. setosus, being a more cold-water and presumably typical Arctic species, would show higher diversification at a molecular level and more pronounced spatial patterns of genetic diversity, but much less dynamic demography. 


\section{Study area}

The Archipelago of Svalbard is situated in the European sector of the Arctic Ocean. In terms of water masses, this area is a transition zone between the Atlantic and Arctic domains. The west coast of its largest island, Spitsbergen, is under the influence of the West Spitsbergen Current (WSC), which transports relatively warm and saline Atlantic water northwards to the Arctic Ocean. The south-eastern part of the archipelago is influenced by the coastal South Cape Current (SCC) that carries cold, less saline Arctic-type water (Piechura et al. 2001; Cottier et al. 2005). Presence, amounts and salinity of water masses in Svalbard fjords result from the local processes and balance between the flows of main Atlantic and Arctic water masses. Therefore, the fjords and their fauna, are potentially sensitive indicators of environmental change (Svendsen et al. 2002; Cottier et al. 2005; Nilsen et al. 2008).

The Svalbard coast consists mainly of low gravel and stony beaches, with several tidal glacier cliffs, moraine lagoons, and frequent rocky peninsulas with half-submerged skerries (Węsławski et al. 1993). The intertidal zone of Svalbard was described by Węsławski et al. (1993), and its recent changes by Węsławski et al. (2010). The source material for the Gammarus occurrence observations in Svalbard is presented on the Svalbard Intertidal Project website http://www.iopan.gda. $\mathrm{pl} /$ projects/SIP/.

\section{Materials and methods}

\section{Sampling and morphological identification}

The material was gathered in the intertidal zone around Svalbard Archipelago, in late July and early August of 2015 and 2016, when neither fast ice nor sea ice was present on the shore (Fig. 1, Table 1). The amphipods were collected at 15 sampling sites, under the stones, each time from the surface of c.a. $1 \mathrm{~m}^{2}$. The collection took place during low tide in lower intertidal, with the use of hand net to catch individuals under the loose, flat stones. The samples were sorted at a site and immediately fixed in $96 \%$ ethanol. In total 389 specimens of gammarids were collected. They were observed and identified to species level under the stereomicroscope NIKON SMZ800 with the use of available keys (Lincoln 1979; Stephensen 1940). The material has been kept in the permanent collection of the Institute of Oceanology, Polish Academy of Sciences.

\section{Molecular analysis}

Three pleopods were cut out with a sharp-edged tweezers from each individual. The total DNA extraction was performed with phenol-chloroform (Hillis et al. 1996) and/ or Chelex (Casquet et al. 2012) procedures. In case of

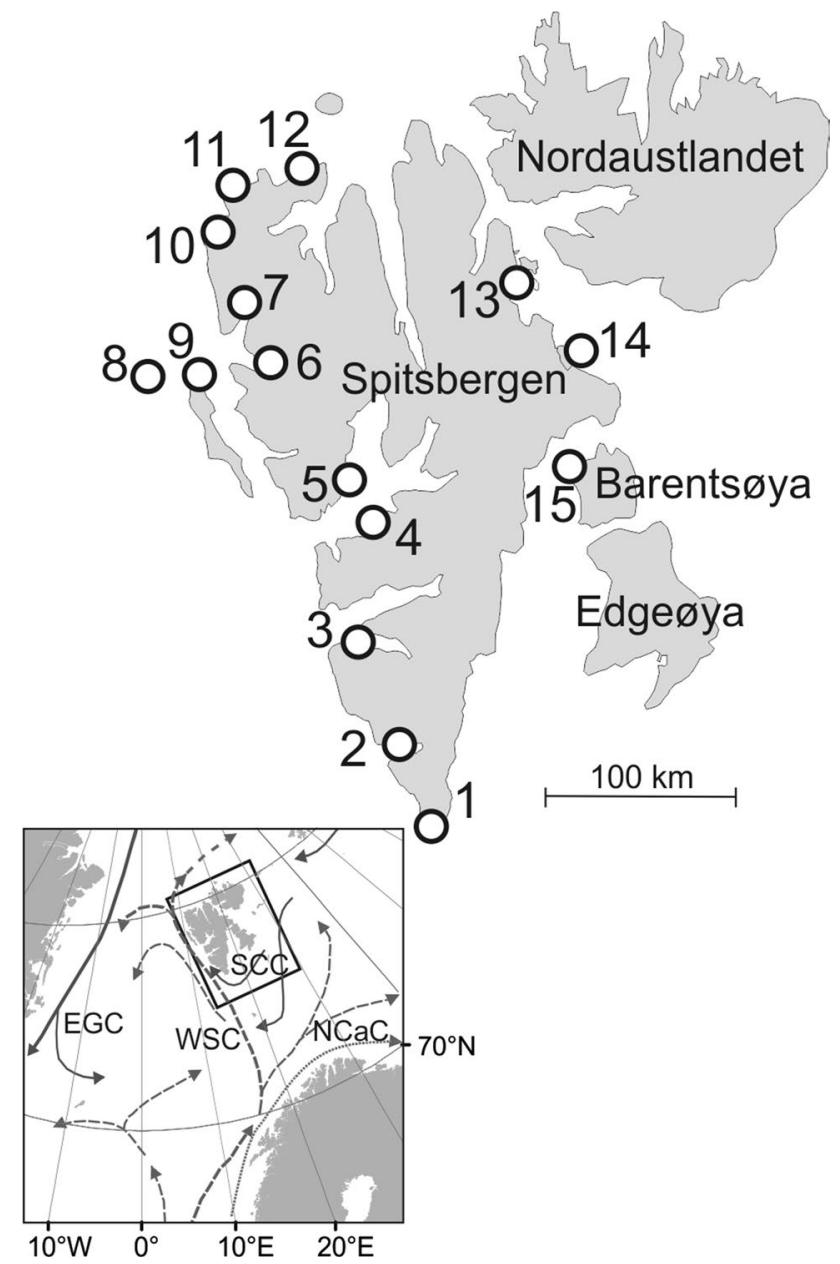

Fig. 1 Map of Svalbard Archipelago with sampling sites and main ocean currents: dashed lines-warmer and transformed currents, solid lines-cold currents; WSC West Spitsbergen Current, SCC South Cape Current, EGC East Greenland Current, $\mathrm{NCaC}$ North Cape Current

phenol-chloroform method the muscle tissue was incubated overnight at $55^{\circ} \mathrm{C}$ in a $1.5 \mathrm{ml}$ tube containing $200 \mu \mathrm{l}$ of Queen's lysis buffer (Seutin et al. 1991) and $5 \mu$ of proteinase $\mathrm{K}(20 \mathrm{mg} / \mathrm{ml})$. The collection of extracts is kept in the Department of Invertebrate Zoology and Hydrobiology, University of Lodz and in the Department of Ichthyology and Hydrobiology, St.-Petersburg University, Russia. The mitochondrial marker COI (Cytochrome $c$ oxidase subunit I), ca. $670 \mathrm{bp}$ in length, was chosen for PCR amplification according to the Hou et al. (2007) procedure with HCO2198/LCO1490 (Folmer et al. 1994) and HCO JJ/LCO JJ (Astrin and Stuben 2008) primer pairs. The PCR was performed in a total volume of $10 \mu \mathrm{l}$ containing $5 \mu \mathrm{l}$ of DreamTaq Master Mix (2x) Polymerase (Fermentas), $0.8 \mu \mathrm{l}$ of each primer (concentration $5 \mathrm{lM}$ ), $2.4 \mu \mathrm{l}$ ultrapure $\mathrm{H}_{2} \mathrm{O}$ and $1 \mu \mathrm{l}$ of DNA template. A $2 \mu \mathrm{l}$ aliquot of the PCR products was visualized in Midori Green-stained 
Table 1 Sampling details: name and position of a site, date and the number of G. oceanicus and G. setosus sequences obtained for a sampling site

\begin{tabular}{|c|c|c|c|c|c|c|c|}
\hline & Sampling site & Region & Latitude $[\mathrm{N}]$ & Longitude [E] & Date & G. oceanicus & G. setosus \\
\hline 1 & Sørkapp & South Spitsbergen & $76^{\circ} 27.958$ & $16^{\circ} 35.507$ & 09.08 .2015 & 20 & 0 \\
\hline 2 & Hornsund & & $76^{\circ} 53.908$ & $15^{\circ} 31.154$ & 12.08 .2015 & 33 & 4 \\
\hline 3 & Bellsund & & $77^{\circ} 32.807$ & $14^{\circ} 33.777$ & 14.08 .2015 & 26 & 4 \\
\hline 4 & Isfjorden South & West Spitsbergen & $78^{\circ} 04.788$ & $13^{\circ} 43.218$ & 17.08 .2015 & 21 & 3 \\
\hline 5 & Isfjorden North & & $78^{\circ} 12.134$ & $12^{\circ} 59.406$ & 23.07.2015 & 28 & 7 \\
\hline 6 & Kongsfjorden & & $78^{\circ} 11.508$ & $15^{\circ} 10.086$ & 02.08 .2016 & 14 & 4 \\
\hline 7 & Krossfjorden & & $79^{\circ} 18.983$ & $11^{\circ} 31.733$ & 01.08 .2016 & 0 & 12 \\
\hline 8 & Prins Karls Forland North & Prins Karls Forland & $78^{\circ} 53.832$ & $10^{\circ} 27.912$ & 08.08 .2016 & 37 & 22 \\
\hline 9 & Prins Karls Forland North-East & & $78^{\circ} 53.922$ & $10^{\circ} 30.335$ & 06.08 .2016 & 33 & 7 \\
\hline 10 & Smeerenburgfjorden & North-West Spitsbergen & $79^{\circ} 38.446$ & $10^{\circ} 58.994$ & 26.07 .2015 & 2 & 17 \\
\hline 11 & Magdalenefjorden & & $79^{\circ} 31.573$ & $10^{\circ} 41.633$ & 25.07 .2015 & 37 & 4 \\
\hline 12 & Sallyhamna & & $79^{\circ} 49.023$ & $11^{\circ} 35.940$ & 27.07 .2015 & 22 & 4 \\
\hline 13 & Hinlopen Strait North & North Spitsbergen & $80^{\circ} 03.644$ & $16^{\circ} 14.391$ & 30.07 .2015 & 6 & 9 \\
\hline 14 & Hinlopen Strait East & North-East Spitsbergen & $79^{\circ} 03.403$ & $20^{\circ} 07.080$ & 04.08 .2015 & 0 & 9 \\
\hline 15 & Barentsøya & Barentsøya & $78^{\circ} 35.108$ & $21^{\circ} 06.541$ & 05.08 .2015 & 0 & 4 \\
\hline
\end{tabular}

(Nippon Genetics) $1.0 \%$ agarose gels to check PCR product quality and length. The PCR products were purified with Exo-FastAP (Thermo Scientific) (Werle et al. 1994) and sequenced with BigDye terminator technology by Macrogen Inc., Korea.

The obtained sequences were edited, aligned with ClustalW algorithm and trimmed to a length of $598 \mathrm{bp}$ using the BioEdit software, ver. 7.2.4 (Hall 1999). To verify the identity of the sequences, they were checked against the content of the GenBank (Benson et al. 2005) and the Barcode of Life Database (BOLD) (Ratnasingham and Hebert 2007). Then, the sequences were deposited in GenBank (accession numbers MH271707-MH272095) and in BOLD (datasets: https://doi.org/10.5883/bold:aaa1262, https:// doi.org/10.5883/bold:aby7004, https://doi.org/10.5883/ bold:abz4044, https://doi.org/10.5883/bold:ace3104, https ://doi.org/10.5883/bold:ace3105, https://doi.org/10.5883/ bold:ace4619).

We also used sequence data deposited already in BOLD Systems by other investigators for comparison with our results.

The haplotypes were identified with DnaSP 6 (Librado and Rozas 2009) while the relationships between them were illustrated with Minimum Spanning Network (MSN) in PopART 1.7 (Bandelt et al. 1999).

In order to examine the level of cryptic diversity within the investigated species, the Molecular Operational Taxonomic Units (MOTU) were identified with the distancebased barcode-gap approach using both the Automatic Barcode Gap Discovery (ABGD) method (Puillandre et al. 2012) and the Barcode Index Numbers (BINs) ascribed to the sequences by BOLD (Ratnasingham and Hebert 2013).
To illustrate haplotype and/or MOTU distribution around Svalbard, a series of non-metric multidimensional scaling plots (nMDS) was performed in PRIMER 7.0 (Clarke and Warwick 1994). The analysis was conducted on the standardized proportion of haplotypes for G. oceanicus, while in the case of $G$. setosus separate plots were performed for all MOTUs and, separately, for the most diverse and haplotyperich MOTU A and MOTU B. To illustrate which haplotype and/or MOTU influenced the distribution of samples in a given plot, overlay vectors were shown based on multiple correlations of haplotype or MOTU proportions among sampling sites.

\section{Phylogeny}

The time calibrated within-species phylogeny of G. setosus was reconstructed, using all identified haplotypes, with Bayesian methodology in BEAST v. 1.8.2 software package (Drummond et al. 2012). A haplotype of G. oceanicus from the present study was chosen as an outgroup. Three, $10 \mathrm{M}$ iterations long runs of Monte Carlo Markov Chains (MCMC), sampled each 1000 iterations, were performed. The strict molecular clock was calibrated with the standard mitochondrial rate for arthropod COI equal to 0.0115 substitution per million years per base pair (Brower 1994). Such rate was accepted as a reasonable midpoint approximation for Gammarus taking into account the recently published cross-validations for other Gammarus species, based on the independent calibration points (Grabowski et al. 2017). The runs were examined in Tracer v1.6 (Rambaut et al. 2014), so they reached the values of effective sampling size (ESS) of at least 200 for each parameter. The Yule speciation process 
(Gernhard 2008) and the Hagesava-Kishino-Yano (HKY) model of evolution chosen in jModel Test 2 (Darriba et al. 2012) were set as priors. All runs were combined using LogCombiner with removal of $10 \%$ burn-in phase; the final tree was summarized with TreeAnnotator, both programs being part of the BEAST 1.8.2 software.

\section{Demography}

The demography of both, G. oceanicus and G. setosus, populations in Spitsbergen was analyzed with mismatch distribution, under a sudden demographic and spatial expansion models, with 1000 bootstrap replicates, in Arlequin 3.5.1.3 software with Rcmd plug-in (Excoffier and Lischer 2010, 2011). We verified the validity of both models with the sum of squared deviations (SSD) between observed and expected mismatches and by the Harpending's Raggedness statistics (HRI). We also tested for recent demographic expansion in both species with two mutation neutrality tests, Tajima's D (Tajima 1989) and Fu's Fs (1997), also implemented in Arlequin, with 1000 simulation as evaluation for test significance. We used the same software to test for the genetic dissimilarities between populations of both species, sampled at different localities around Spitsbergen with the $\mathrm{F}_{\text {st }}$ estimator, as well as by the exact test for population differentiation based on haplotype frequencies (Raymond and Rousset 1995), using default program set-ups.

The fluctuations of demography over time was illustrated with the extended Bayesian Skyline Plot (eBSP), reconstructed in BEAST v1.8.2 and based on three runs of MCMC $20 \mathrm{M}$ iterations long, and sampled every 1000 iterations. Taking into account that even small differences in accepted mutation rate may produce large shifts in time estimations for very recent demographic events, we performed preliminary analyses, each with different mutation rate based on different calibration schemes for Gammarus: 0.0113, 0.0129 (Grabowski et al. 2017), 0.0165 (CopilaşCiocianu and Petrusek 2017) and the standard rate of 0.0115 (Brower 1994). The runs did not differ substantially and eventually the standard rate of 0.0115 was applied for analysis as a reasonable midpoint approximation. The runs were examined in Tracer v1.6 (Rambaut et al. 2014). The Hagesava-Kishino-Yano (HKY) model of evolution chosen in jModel Test 2 (Darriba et al. 2012) was set as prior. The eBSP plot was produced in MS Excel.

\section{Results}

In the material collected from a total of 15 sampling localities around Svalbard, we found 110 individuals of $G$. setosus at 14 sites and 279 individuals of $G$. oceanicus at 12 sites. Both species co-occurred at 11 sampling sites (Table 1). The morphological identification of all the collected individuals was confirmed with DNA barcodes.

The 389 COI sequences were ascribed to 20 haplotypes within G. setosus and 22 haplotypes within G. oceanicus. The reticulate topology of the Minimum Spanning Network illustrating phylogenetic relationships between haplotypes of G. setosus suggests rather long history of divergence within the species around Svalbard and presence of five distinct lineages (Fig. 2). In contrast, the populations of G. oceanicus appear genetically uniform and the star-like topology of the network implies a recent population expansion in the area (Fig. 2).

The delimitation of MOTUs, both with the ABGD and BIN algorithms, indicated the presence of cryptic diversity with five MOTUs and BINs within G. setosus (MOTU: BIN): A: ABY7004, B: ABZ4044, C: ACE3104, D: ACE3105, E: ACE4619. In contrast, all the individuals of G. oceanicus from Svalbard were grouped within the same MOTU/BIN (AAA1262) (Fig. 2). The topology of the COIbased Bayesian chronogram suggests that the $G$. setosus MOTUs started to diverge already in early Pleistocene, at ca. 1.5 Ma (Fig. 3).

Illustration of the distribution of $G$. setosus haplotypes and MOTUs around Svalbard implied at least some geographical structuring, despite presence and high share of the most common MOTU A in all the sites where the species was found (Figs. 2 and 4). Interestingly, MOTU A was the only one recorded in the southern Spitsbergen. Another common and highly frequent MOTU B was present elsewhere with the exception of North-East Spitsbergen. However, we cannot exclude that it may be an effect of undersampling. The remaining MOTUs were present in a few disjunct localities around Svalbard, with the exception of southern Spitsbergen. A closer look into the haplotype distribution within the most common MOTUs shows high frequency of the abundant haplotype 1 in samples from the West, NorthWest and South Spitsbergen and of haplotype 4 in the West Spitsbergen, both within MOTU A (Fig. 5). There was also a high frequency of haplotype 3 , belonging to MOTU B, at stations located on Prins Karls Forland and West Spitsbergen (Fig. 5).

In $G$. oceanicus, the illustration of geographic distribution of haplotypes showed some, however little pronounced, spatial genetic population structure around Svalbard (Figs. 2, 4). Only the nMDS analysis (Fig. 5) allowed for distinction of two main sampling site groups differing by the haplotype domination structure: first with sites (from Isfjorden and East Hinlopen Strait) dominated by haplotype 1, and second with other sites (from Prins Karls Forland, South and North-West Spitsbergen) where the haplotype 2 was most frequent. The only exception was the sample from Kongsfjorden, where the haplotypes 2 and 14 co-dominated. The $\mathrm{F}_{\mathrm{ST}}$ values were generally low (usually much lower than 0.3 ) (Fig. 6). It is also 


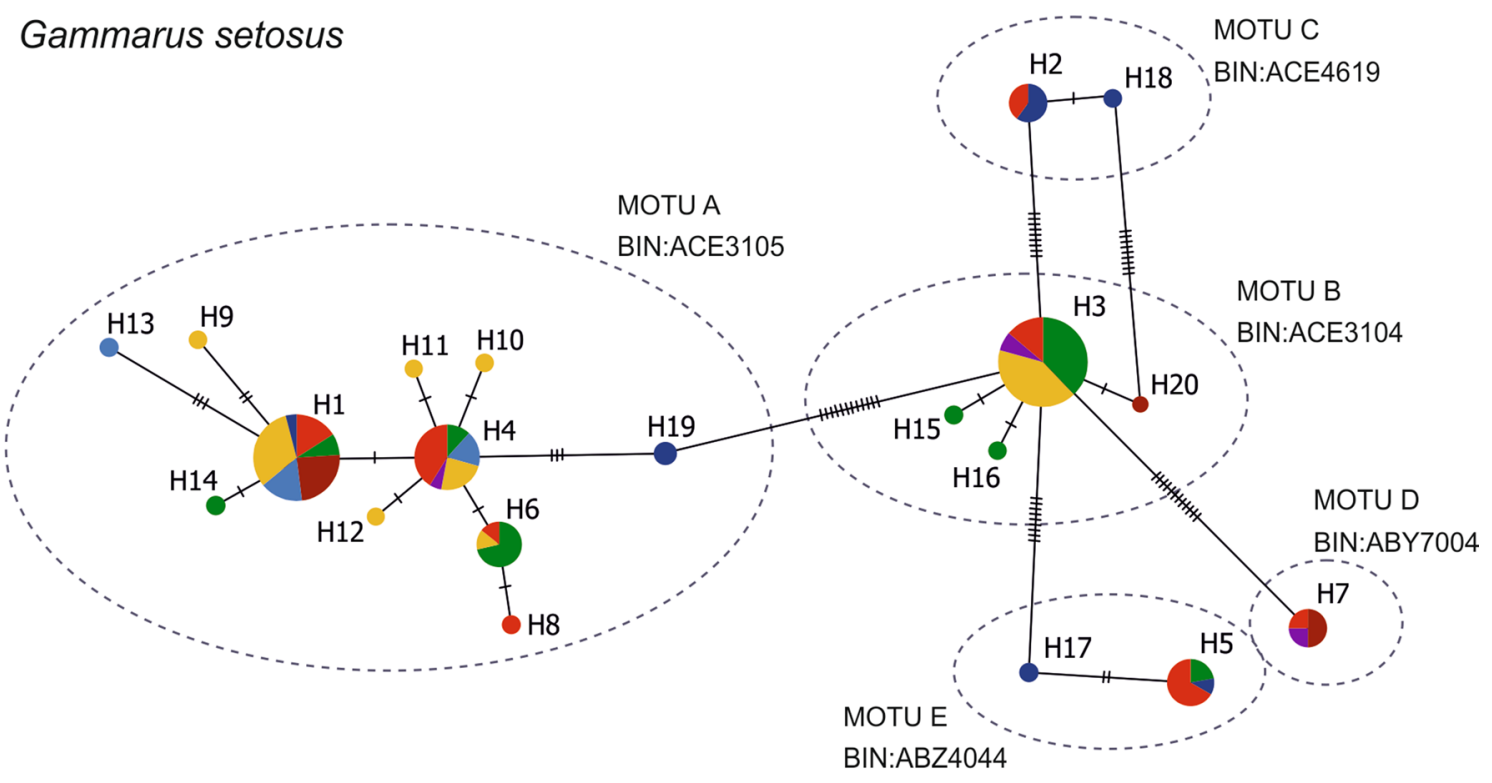

Gammarus oceanicus - BIN:AAA1262

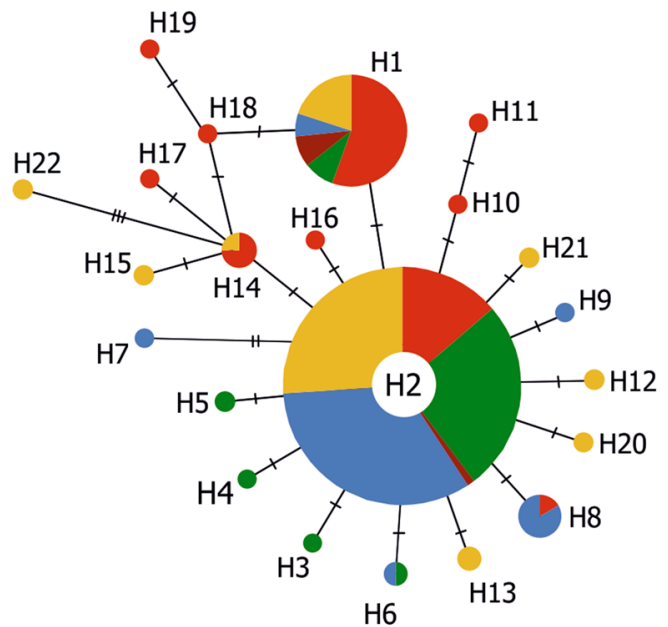

Region legend

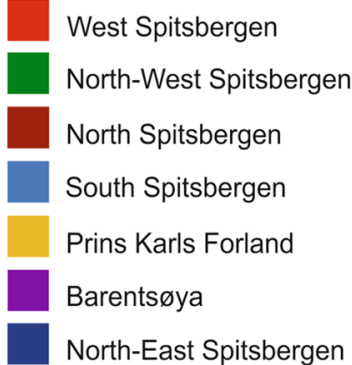

Fig. 2 Minimum Spanning Network (MSN) indicating phylogenetic relationships among haplotypes of Gammarus setosus and Gammarus oceanicus with MOTU and BIN labels

important to stress that the significant $F_{\mathrm{ST}}$ values measured for $G$. oceanicus overlapped (with one exception) with the significant differences provided by exact test for population differentiation (Table Suppl. 1, Fig. 6). On the other hand, regarding $G$. setosus, the significant $\mathrm{F}_{\mathrm{ST}}$ values only in about half of the cases pointed to the same pairs of sampling areas as did the results of the exact test for population differentiation (Table Suppl. 2, Fig. 6).

Mismatch analysis and the associated neutrality tests showed no traces of recent demographic expansion of $G$. setosus around Svalbard, however some degree of spatial expansion could not be excluded. The results of eBSP show that the population of G. setosus in Svalbard could contract in Late Pleistocene, ca. $30 \mathrm{ka}$. The population have possibly started to expand at ca. $20 \mathrm{ka}$, however the very high span of the HPD intervals confounds unequivocal interpretation (Fig. 7).

In case of G. oceanicus, both, the mismatch analysis and the neutrality tests clearly suggest that its population around Svalbard is in the stage of demographic and spatial expansion (Table 2). The eBSP revealed that the rapid 


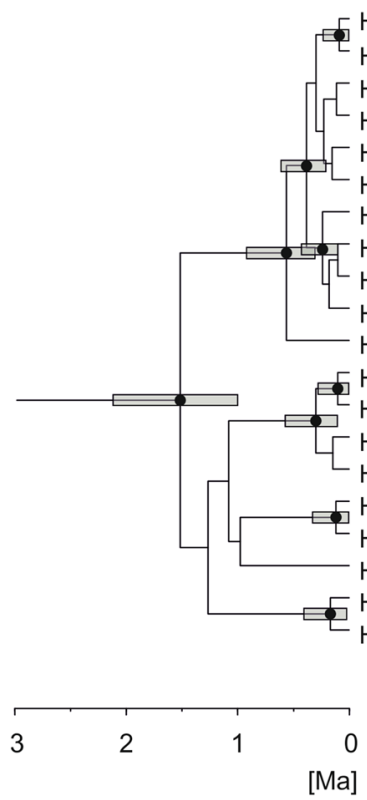

Fig. 3 Time-calibrated Bayesian phylogenetic chronogram of Gammarus setosus, based on the cytochrome oxidase I sequences (COI) [capitals mark MOTUs followed by BIN numbers; circles at nodes indicate $\mathrm{PP}>0.8]$

B - BOLD:ACE3104

C - BOLD:ACE4619

I - BOLD:ABY7004

E - BOLD:ABZ4044

\section{A - BOLD:ACE3105 Discussion}

Our study shows contrasting, to some extent, patterns in molecular diversity and demography of the two sibling gammarids, G. oceanicus and G. setosus, dominating intertidal communities in Svalbard. Most recently, Węsławski et al. (2018) observed that, during the last 20-30 years, the former species has expanded its distribution range by over $1300 \mathrm{~km}$ along the west and north coasts of Spitsbergen. They reported also a dominating position of $G$. oceanicus on the number of sites, where it was previously just an occasional species, while $G$. setosus has remained where it was observed already three decades ago. We observed absence of cryptic diversity within G. oceanicus from Svalbard, star-like topology of haplotype network and lack of spatially structured genetic differentiation, yet with relatively high number of weakly divergent haplotypes (Fig. 2). Such features are frequently observed in recent colonizers with high propagule pressure (e.g. Haydar et al. 2011; Rewicz et al. 2015). Also the set of demographic analyses we performed, points out to a recent demographic and spatial expansion of the species. However, our eBSP analysis suggests, that G. oceanicus has started to expand already in

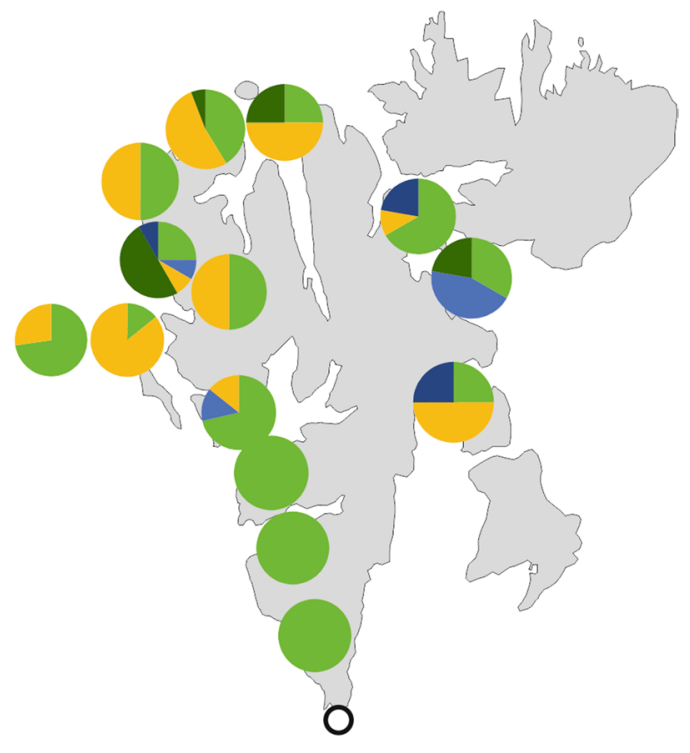

G. setosus - MOTU

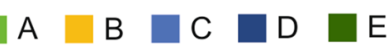

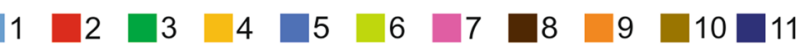 \\ $12 \square 13 \square 14 \square 15 \square 16 \square 17 \square 18 \square 19 \square 20 \square 21 \square 22$}

Fig. 4 Frequency of Gammarus oceanicus haplotypes and Gammarus setosus MOTUs in sampling sites. White circles indicate absence of the species at the sampling site 


\section{G. oceanicus - haplotypes}

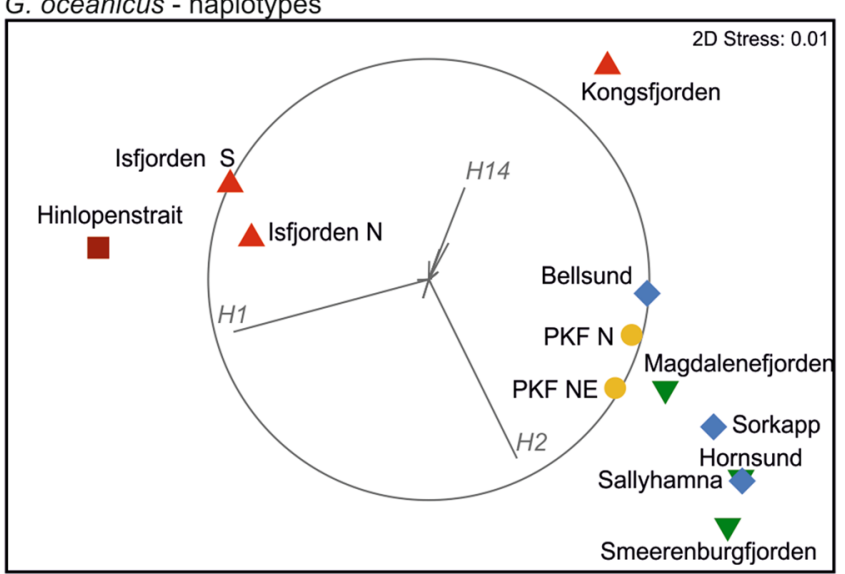

G. setosus - MOTU A

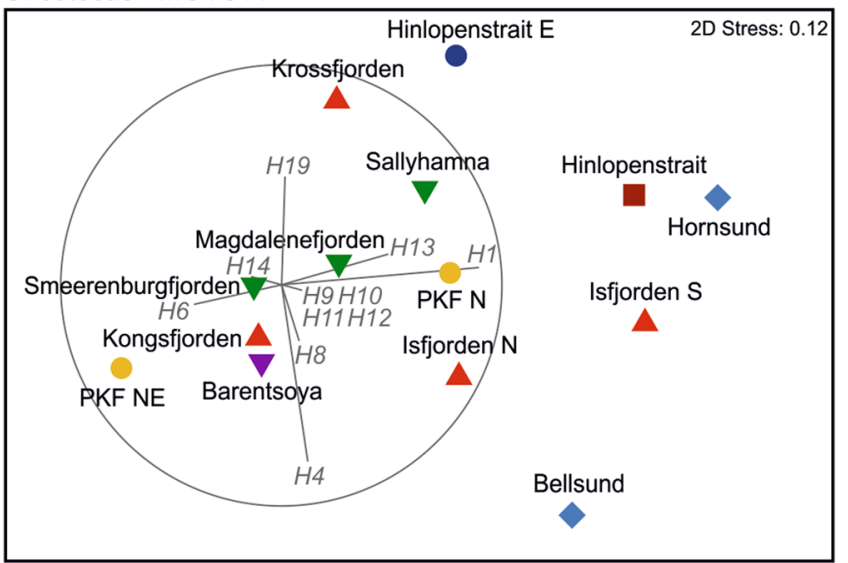

G. setosus - all MOTUs

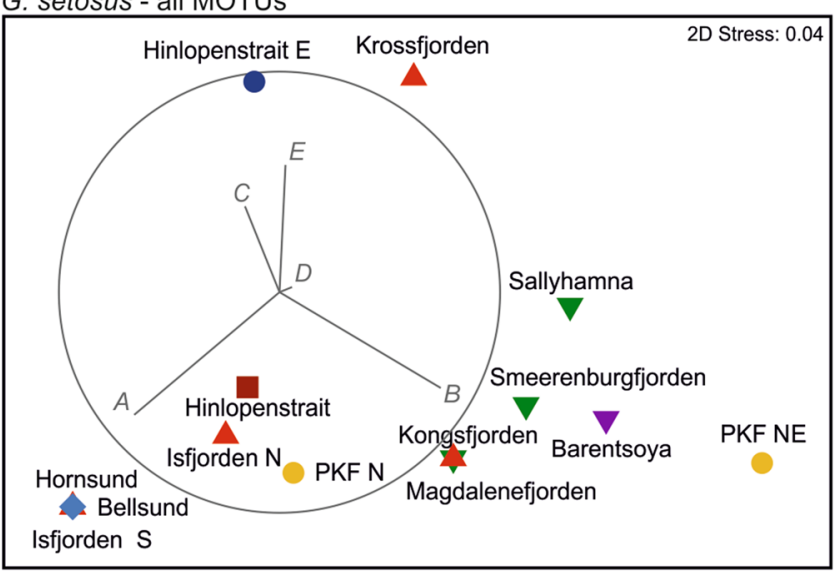

G. setosus - MOTU B

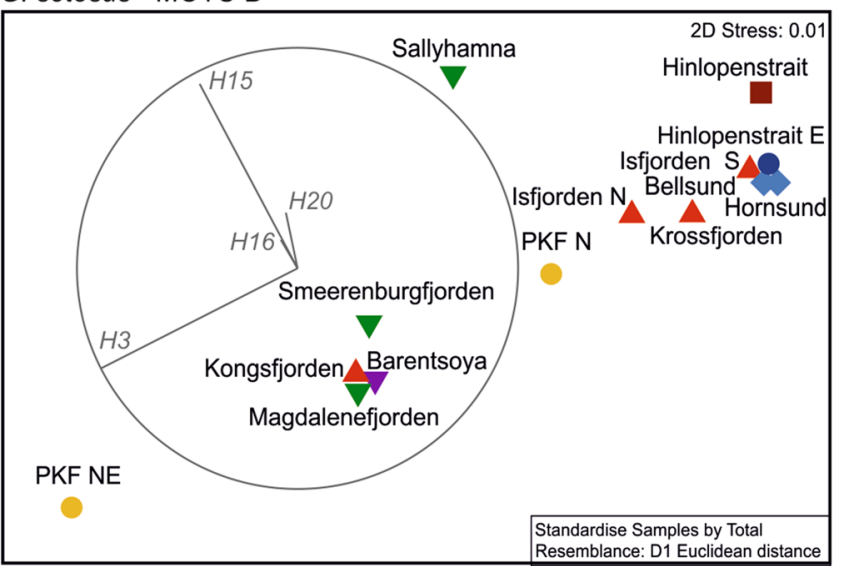

Region: Prins Karls Forland South Spitsbergen $\Delta$ West Spitsbergen $\nabla$ North-West Spitsbergen

North Spitsbergen

North-East Spitsbergen

$\nabla$ Barentsoya

Fig. 5 Multidimensional Scaling (MDS) plots illustrating distribution of Gammarus oceanicus and Gammarus setosus haplotypes in the study area
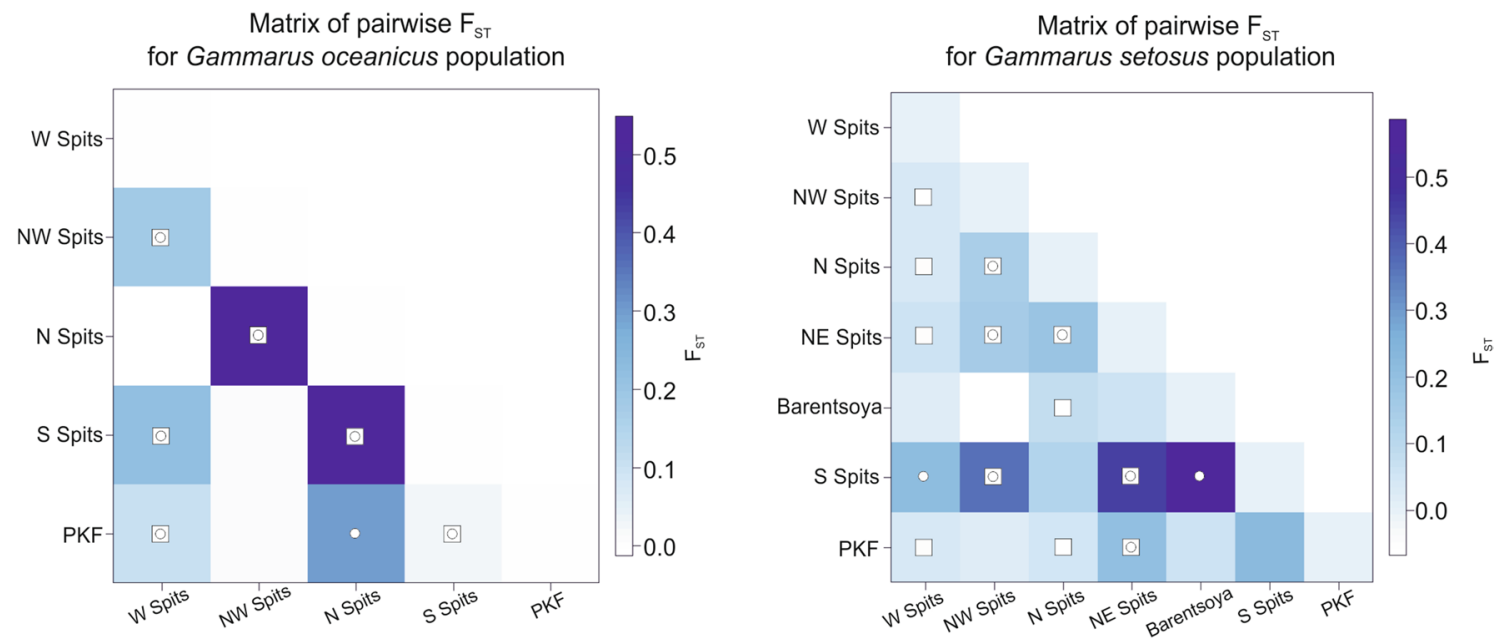

Fig. 6 Population connectivity illustrated by a matrix of pairwise $F_{\mathrm{ST}}$ values for Gammarus oceanicus and for Gammarus setosus. White dots indicate significant $F_{\mathrm{ST}} P$ values, white squares show significant differences revealed by the exact test for population differentiation 

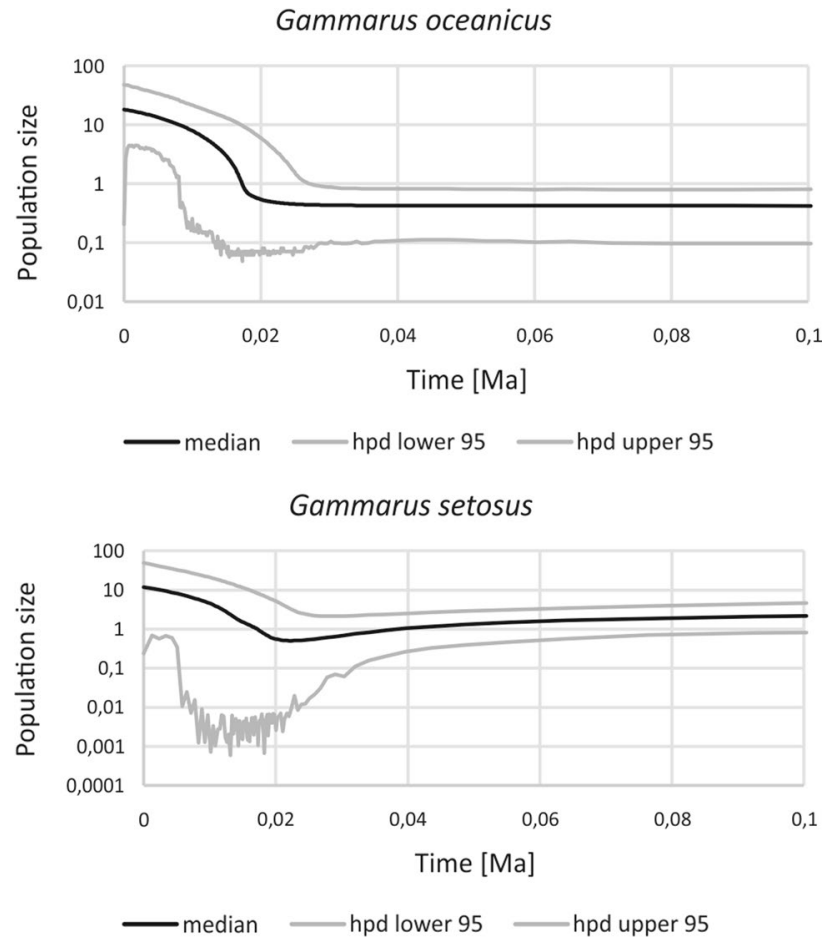

Fig. 7 Extended Bayesian Skyline Plot (EBSP) showing changes in population demography of Gammarus oceanicus and Gammarus setosus late Pleistocene, around the end of the Last Glacial Maximum (LGM), at ca. $18 \mathrm{ka}$ (Fig. 5) and not only during the recent decades, as observed by Węsławski et al. (2018). Such results were observed for other North Atlantic intertidal macroinvertebrates with typically boreal distribution. They include e.g. the snail Littorina obtusata, crustaceans such as Semibalanus balanoides and Idotea balthica (Wares and Cunningham 2001) as well as the Arctic planktonic copepods Calanus glacialis (Weydmann et al. 2018). Such an early onset of expansion of boreal marine species may be explained by the relatively milder conditions along the northern European shores, if compared to Western Atlantic, that enabled the existence of vast refugial areas extending from as much north as Faroe Islands to Northern Africa (e.g. Ingólfsson 1992; Kettle et al. 2011; Waltari and Hickerson 2013). Thus, it seems that the mass colonisation of Svalbard by $G$. oceanicus in the last few decades can be considered as another step forward in the ongoing post-glacial expansion of this species. Apparently, this expansion has been greatly intensified by the recent climatic changes, but it has not left any specific signature in the genetic structure of the local populations.

A question arises, where to look for the source of this colonisation and for initial refugia from which the expansion northwards started. The Svalbard population represents the same MOTU as the populations inhabiting North Sea/ European Atlantic coast, Baltic Sea and the White Sea. On the other hand, the North American boreal coast can be

Table 2 Results of mismatch distribution analysis and Tajima's D and Fu's FS neutrality tests for Gammarus oceanicus and Gammarus setosus populations in Svalbard

\begin{tabular}{|c|c|c|c|c|c|c|c|c|}
\hline & \multirow{2}{*}{\multicolumn{2}{|c|}{$\frac{\text { Gammarus oceanicus }}{\text { Total in Svalbard }}$}} & \multicolumn{6}{|c|}{ Gammarus setosus } \\
\hline & & & \multicolumn{2}{|c|}{ Total in Svalbard } & \multicolumn{2}{|l|}{ MOTU A } & \multicolumn{2}{|l|}{ MOTU B } \\
\hline & $\begin{array}{l}\text { Demo- } \\
\text { graphic } \\
\text { expansion }\end{array}$ & $\begin{array}{l}\text { Spatial expan- } \\
\text { sion }\end{array}$ & $\begin{array}{l}\text { Demo- } \\
\text { graphic } \\
\text { expansion }\end{array}$ & $\begin{array}{l}\text { Spatial expan- } \\
\text { sion }\end{array}$ & $\begin{array}{l}\text { Demo- } \\
\text { graphic } \\
\text { expansion }\end{array}$ & $\begin{array}{l}\text { Spatial expan- } \\
\text { sion }\end{array}$ & $\begin{array}{l}\text { Demo- } \\
\text { graphic } \\
\text { expansion }\end{array}$ & $\begin{array}{l}\text { Spatial } \\
\text { expansion }\end{array}$ \\
\hline SSD & 0.00314 & 0.00314 & 0.03856 & 0.02201 & 0.00378 & 0.00378 & 0.00107 & 0.00025 \\
\hline $\begin{array}{l}\text { Model }(\mathrm{SSD}) p \\
\text { value }\end{array}$ & 0.14000 & 0.00000 & 0.01000 & 0.48000 & 0.33000 & 0.25000 & 0.41000 & 0.46000 \\
\hline $\begin{array}{l}\text { Raggedness } \\
\text { index }\end{array}$ & 0.12249 & 0.12249 & 0.03412 & 0.03412 & 0.07588 & 0.07588 & 0.44235 & 0.44235 \\
\hline $\begin{array}{l}\text { Raggedness } p \\
\text { value }\end{array}$ & 0.16000 & 0.23000 & 0.02000 & 0.85000 & 0.24000 & 0.26000 & 0.69000 & 0.66000 \\
\hline \multicolumn{9}{|l|}{ Tajima's D test } \\
\hline Sample size & 286 & & 115 & & 55 & & 32 & \\
\hline Tajima's $D$ & -2.25319 & & -0.06996 & & -2.23956 & & -1.72954 & \\
\hline $\begin{array}{l}\text { Tajima's } D p \\
\text { value }\end{array}$ & 0.00000 & & 0.54900 & & 0.00100 & & 0.01800 & \\
\hline \multicolumn{9}{|l|}{ Fu's FS test } \\
\hline No. of alleles & 23 & & 24 & & 10 & & 4 & \\
\hline Fu's FS & -29.26619 & & 0.58605 & & -2.55215 & & -3.48995 & \\
\hline Fu's FS $p$ value & 0.00000 & & 0.63100 & & 0.08800 & & 0.00000 & \\
\hline
\end{tabular}


excluded as another, genetically divergent, MOTU inhabits this area. Then, the Canadian Arctic population contains just a small subset of the haplotypes found in European Arctic, suggesting recent westward colonization (BOLD Systems, Krebes et al. 2011, Radulovici 2012). Of the European seas, the Baltic emerged as a freshwater Baltic Ice Lake (BIL) at ca. $16 \mathrm{ka} \mathrm{BP}$, after the retreat of the ice-sheet. Then it passed through brackish and purely freshwater phases, and only since ca. 8 ka regained its connection to the North Sea and present brackish water conditions (Björck 1995; Andrén et al. 2011). Thus it is highly doubtful as the glacial refugium for G. oceanicus, and the population present in this basin, is presumably also of a very recent origin. This leaves either the North Sea/European Atlantic Coast or the White Sea as the potential refugia. However, at this stage we cannot discriminate between the two for the absence of reliable reference data and insufficient sampling in these areas. In most already studied cases of species that expanded post-glacially to the Arctic, the North Sea/European Atlantic Coast is the most plausible refugium (Wares and Cunningham 2001; Maggs et al., 2008). Such direction of colonization would be also favored by the local system of sea currents (Beszczynska-Möller et al. 2011; Fig. 1). Interestingly, fossil data show that in late Pleistocene/early Holocene the ocean quahog (Arctica islandica), showing at present similar distribution as G. oceanicus, occurred in the Bay of Biscayne and Mediterranean as well as along the Siberian coast adjacent to the present White Sea (Dahlgren et al. 2000). Thus, however no fossil data is available in this case, we cannot exclude a similar situation and colonization of Arctic from two refugia in case of G. oceanicus.

The climatic conditions in High Arctic during the LGM are still disputable. The reconstructions of the ice extent over Svalbard and the adjacent sea in late Weichselian range from almost no ice (Troitsky et al. 1979, Boulton et al. 1982) to thick ice-cover extending to the western shelf edge of the Barents Sea as well as north of Svalbard (Schytt et al. 1968; Mangerud et al. 1998; Landvik et al. 1998). More recent studies, both geological and phylogeographical, agree that at least limited areas in High Arctic remained unglaciated through LGM, providing microrefugia for Pleistocene terrestrial biota (Funder 1979; Brochmann et al. 2003; Landvik et al. 2003; Klütsch et al. 2017). Concerning marine shelf refugia, it is known that continental shelf areas reduced greatly all over the world, due to the general eustatic sea level regression during LGM (Clark and Mix 2002; Boehme et al. 2012). In the Arctic, vast coastal areas were presumably covered by ice sheets and glaciers (Clark and Mix 2002; Lambeck et al. 2002). Yet, several studies pointed out to presence of Arctic and periglacial refugia for various marine taxa, e.g. along the Norwegian coast, Island and Beringia (for summary and discussion see Hardy et al. 2011). The high cryptic diversity of G. setosus in the Svalbard archipelago, with five MOTUs of Pleistocene age (Fig. 3) distributed all over this relatively limited area (Fig. 4), is a very surprising discovery. However, it must be stressed that the illustrated distribution patterns may, to some extent, be an artefact resulting from the generally low frequency and abundance of $G$. setosus in samples dominated by $G$. oceanicus.

It suggest a rather long and complex evolutionary history of the species. It must be also taken into account, that G. setosus is a cold-water stenotherm, nowadays typical of Arctic and sub-Arctic waters (Steele and Steele 1970; Węsławski 1991). Thus, two main scenarios may be drawn to explain such diversification pattern: (1) long persistence and local diversification of $G$. setosus in the High Arctic, including Svalbard, during Pleistocene; (2) multiple late glacial and post-glacial colonization of High Arctic by the already diverged MOTUs of $G$. setosus from several, so far unknown, Arctic or periglacial refugia. Concerning the first scenario, so far, there is no evidence for the existence of marine shelf refugia in High Arctic, their presence is also disputable in the adjacent Arctic areas (e.g. Ingólfsson 2009), however the lack of such evidence cannot be treated as an evidence that they did not exist. In situ divergence in High Arctic archipelagos and only geographically limited subsequent recolonizations of formerly glaciated coastlines would be most-parsimonious explanation. Geological studies show that even if, ge, most of the Svalbard coastline and fjords were covered with glaciers, there were also prolonged episodes with much milder and iceless conditions, both on land and in the ocean (Troitsky et al. 1979; Landvik et al. 1998). Thus, presence of patchy distributed ice-free shelf and/or intertidal habitats on Svalbard and other High Arctic archipelagos is quite probable. The first scenario is also supported by our results of the demographic analyses that do not indicate explicit population expansion in Late Pleistocene (Fig. 5), as in the case of other boreal taxa. In such instance, G. setosus in Svalbard would be a Pleistocenic relict. The second scenario should be associated with much more prominent expansion signals, such as in cases of other recently expanded species (Berge et al. 2005; Ware et al. 2013; Berge et al. 2015). However, a few decades ago $G$. setosus was apparently much more abundant in Svalbard, until the very recent expansion of the boreal G. oceanicus (Węsławski et al. 2018). Thus, it cannot be excluded that the latter species outcompeted $G$. setosus what caused a significant reduction of its population size and masked the signal of former demographic/spatial expansion. At this moment there is no available data on molecular diversity and identity of populations in possible refugial areas, such as Iceland, Lofoten or Siberian coast, that could help to back the second scenario.

In case of both species, the $\mathrm{F}_{\mathrm{ST}}$ values between regions were usually lower than 0.3 , which is much less than the 
average level for native gammarids and close to the range of fast spreading invasive gammarids (Baltazar-Soares et al. 2017). Such generally low $F_{S T}$ values suggest high connectivity between different collection sites (Excoffier and Lischer 2011). The discrepancies between the distribution of significant $F_{S T}$ values and significant sample differences measured with the use of the exact test for population differentiation (Fig. 6) could be explained by disproportions in the sample sizes deriving from different regions (Table 1).

Concluding, we have shown for the first time contrasting molecular diversity and demographic patterns in two crustaceans, with different thermal optima, dominant in the Arctic intertidal zone, that currently co-exist in the coastal habitats of the Svalbard Archipelago in High Arctic. The generally boreal G. oceanicus, that has been observed to colonise Svalbard in recent decades, is apparently still in the phase of the post-glacial mass population expansion from extra-Arctic refugia, that is likely to be enhanced by the Atlantification of High Arctic. On the other side, the typically cold-water $G$. setosus seems to have a much longer evolutionary history in the Arctic, where it apparently survived the LGM. Yet, its demography is much less dynamic than that of the former species. Very low number of haplotypes in some MOTUs may even reflect population decline associated with mass expansion of G. oceanicus. This points out to the necessity for further studies upon the still understudied molecular biogeography patterns in High Arctic biota, that may be heavily influenced by the recent climatic changes.

Acknowledgements Molecular work at the University of Lodz was financed by the NCN Project No. 2014/15/B/NZ8/00266 and by the university statutory funds. The Centre for Molecular and Cell Technologies of St. Petersburg State University is acknowledged for technical help. Sampling has been performed during Svalbard Intertidal Project expeditions, supported by Sysselmannen pa Svalbard Miljovernfond RIS 3423 and Polish Ministry of Science support fund SPUB-SIP 2017, https://www.iopan.pl/projects/SIP/SIP_2015/index.html.

\section{Compliance with ethical standards}

Conflict of interest The authors declare that they have no conflict of interest.

Ethical approval All applicable international, national, and institutional guidelines for the use of animals were followed. The studied species neither are threatened by extinction. They are also not subjected to any other national or international legal restrictions. The samples were collected within the official sampling campaigns supported by Sysselmannen pa Svalbard Miljovernfond (Norway) and Ministry of Science and Higher Education (Poland), with no harm to the local environment and in compliance with all the legal regulations and approvals, both from the Norwegian and Polish authorities.

Open Access This article is distributed under the terms of the Creative Commons Attribution 4.0 International License (http://creativeco mmons.org/licenses/by/4.0/), which permits unrestricted use, distribution, and reproduction in any medium, provided you give appropriate credit to the original author(s) and the source, provide a link to the Creative Commons license, and indicate if changes were made.

\section{References}

ACIA (2005) Impacts of a warming Arctic: Arctic climate impact assessment. Cambridge University Press, New York

Andrén TU, Björck S, Andrén E, Conley D, Zillén L, Anjar J (2011) The development of the Baltic Sea Basin during the last $130 \mathrm{ka}$. In: Harff J et al (eds) The Baltic Sea Basin, Central and Eastern European Development Studies (CEEDES). Springer, Berlin. https://doi.org/10.1007/978-3-642-17220-5_4

Astrin JJ, Stuben PE (2008) Phylogeny in cryptic weevils: molecules, morphology and new genera of western Palaearctic Cryptorhynchinae (Coleoptera: Curculionidae). Invertebr Syst 22(5):503-522

Baltazar-Soares M, Paiva F, Chen Y, Zhan A, Briski E (2017) Diversity and distribution of genetic variation in gammarids: comparing patterns between invasive and non-invasive species. Ecol Evol 7:7687-7698. https://doi.org/10.1002/ece3.3208

Bandelt H, Forster P, Röhl A (1999) Median-joining networks for inferring intraspecific phylogenies. Mol Biol Evol 16(1):37-48. https://doi.org/10.1093/oxfordjournals.molbev.a026036

Beaugrand G, Reid PC, Ibañez F, Lindley JA, Edwards M (2002) Reorganization of North Atlantic Marine copepod biodiversity and climate. Nature 296(5573):1692-1694

Benson DA, Karsch-Mizrachi I, Lipman DJ, Ostell J, Wheeler DL (2005) GenBank. Nucleic Acids Res 33:D34-D38. https://doi. org/10.1093/nar/gki063

Berge J, Johnsen G, Nilsen F, Gulliksen B, Slagstad D (2005) Ocean temperature oscillations enable reappearance of blue mussels Mytilus edulis in Svalbard after a 1000 year absence. Mar Ecol Prog Ser 303:167-175

Berge J, Heggland K, Lønne OJ, Cottier F, Hop H, Gabrielsen GW, Nøttestad L, Misund OA (2015) First records of Atlantic Mackerel (Scomber scombrus) from the Svalbard Archipelago, Norway, with possible explanations for the extension of its distribution. Arctic 68(1):54-61. https://doi.org/10.14430/arctic4455

Beszczynska-Möller A, Woodgate RA, Lee CM, Melling H, Karcher M (2011) A synthesis of exchanges through the main oceanic gateways to the Arctic Ocean. Oceanography 24(3):82-99. https ://doi.org/10.5670/oceanog.2011.59

Beuchel F, Gulliksen B (2008) Temporal patterns of benthic community development in an Arctic fjord (Kongsfjorden, Svalbard): results of a 24-year manipulation study. Polar Biol 31:913-924

Björck S (1995) A review of the history of the Baltic Sea, 13.0 8.0 ka BP. Quat Int 27:19-40

Blacker RW (1957) Benthic animals as indicators of hydrographic conditions and climatic change in Svalbard waters. Fish Invest Minist Fish Food 20:1-59

Boehme L, Thompson D, Fedak MA, Bowen WD, Hammill MO, Stenson GB (2012) How many seals were there? The global shelf loss during the last glacial maximum and its effect on the size and distribution of grey seal populations. PLoS ONE 7(12):e53000. https://doi.org/10.1371/journal.pone.0053000

Boulton GS, Baldwin CT, Peacock JD, McCabe AM, Miller G, Jarvis J, Horsefield B, Worseley P, Eyles N, Chroston PN, Day TE, Gibbard P, Hare PE, von Brunn V (1982) A glacio-isostatic facies model and amino acid stratigraphy for late Quaternary events in Spitsbergen and the Arctic. Nature 298:437-441

Brochmann C, Gabrielsen TM, Nordal I, Landvik JY, Elven R (2003) Glacial survival or tabula rasa? The history of North Atlantic biota revisited. Taxon 52:417-450 
Brower AVZ (1994) Rapid morphological radiation and convergence among races of the butterfly Heliconius erato inferred from patterns of mitochondrial DNA evolution. Proc Natl Acad 91(14):6491-6495

Casquet J, Thebaud C, Gillespie RG (2012) Chelex without boiling, a rapid and easy technique to obtain stable amplifiable DNA from small amounts of ethanol-stored spiders. Mol Ecol Resour 12(1):136-141. https://doi.org/10.1111/j.1755-0998.2011.03073.x

Clark PU, Mix AC (2002) Ice sheets and sea level of the last glacial maximum. Q Sci Rev 21:1-7

Clarke KR, Warwick RM (1994) Changes in marine communities: an approach to statistical analysis and interpretation. Natural Environment Research Council, Swindon

Copilaş-Ciocianu D, Petrusek A (2017) The southwestern Carpathians as an ancient centre of diversity of freshwater gammarid amphipods: insights from the Gammarus fossarum species complex. Mol Ecol 24(15):3980-3992. https://doi.org/10.1111/mec.13286

Costa FO, Henzler CM, Lunt DH, Whiteley NM, Rock J (2009) Probing marine Gammarus (Amphipoda) taxonomy with DNA barcodes. Syst Biodivers 7(4):365-379. https://doi.org/10.1017/ S1477200009990120

Cottier FR, Tverberg V, Inall ME, Svendsen H, Nilsen F, Griffiths C (2005) Water mass modification in an Arctic fjord through crossshelf exchange: the seasonal hydrography of Kongsfjord, Svalbard. J Geophys Res 110:C12005. https://doi.org/10.1029/2004J C002757

Dahlgren TG, Weinberg RJ, Halanych KM (2000) Phylogeography of the ocean quahog (Arctica islandica): influences of paleoclimate on genetic diversity and species range. Mar Biol 137:487-495

Darriba D, Taboada GL, Doallo R, Posada D (2012) jModelTest 2: more models, new heuristics and parallel computing. Nat Methods 8:772. https://doi.org/10.1038/nmeth.2109

Drummond AJ, Suchard MA, Xie D, Rambaut A (2012) Bayesian phylogenetics with BEAUti and the BEAST 1.7. Mol Biol Evol 29:1969-1973. https://doi.org/10.1093/molbev/mss075

Excoffier L, Lischer HEL (2010) Arlequin suite ver 3.5: a new series of programs to perform population genetics analyses under Linux and Windows. Mol Ecol Resour 10:564-567. https://doi.org/10.1 111/j.1755-0998.2010.02847.x

Excoffier L, Lischer HEL (2011) Arlequin suite ver 3.5: manual. Swiss Institute of Bioinformatics, Bern, p 174

Fleischer D, Schaber M, Piepenburg D (2007) Atlantic snake pipefish (Entelurus aequoreus) extends its northward distribution range to Svalbard (Arctic Ocean). Polar Biol 30:1359-1362

Folmer O, Black M, Hoeh W, Lutz R, Vrijenhoek R (1994) DNA primers for amplification of mitochondrial cytochrome $\mathrm{c}$ oxidase subunit I from diverse metazoan invertebrates. Mol Mar Biol Biotech 3(5):294-299

Fu Y-X (1997) Statistical tests of neutrality of mutations against population growth, hitchhiking, and background selection. Genetics 147:915-925

Funder S (1979) Ice-age plant refugia in east Greenland. Palaeogeogr Palaeoclimatol Palaeoecol 28:279-295

Gaston KJ, Spicer JI (2001) The relationship between range size and niche breadth: a test using five species of Gammarus (Amphipoda). Glob Ecol Biogeogr 10:179-188

Gerhardt A, Bloor M, Mills CL (2011) Gammarus: important taxon in freshwater and marine changing environments. Int J Zool. https ://doi.org/10.1155/2011/524276

Gernhard T (2008) The conditioned reconstructed process. J Theor Biol 253:769-778. https://doi.org/10.1016/j.jtbi.2008.04.005

Grabowski M, Mamos T, Bącela-Spychalska K, Rewicz T, Wattier RA (2017) Neogene paleogeography provides context for understanding the origin and spatial distribution of cryptic diversity in a widespread Balkan freshwater amphipod. PeerJ 5:e3016. https ://doi.org/10.7717/peerj.3016
Greene CH, Pershing AJ, Cronin T, Ceci N (2008) Arctic climate change and its impacts on the ecology of the North Atlantic. Ecology 89(11):S24-S38

Hall TA (1999) BioEdit: a user-friendly biological sequence alignment editor and analysis program for Windows 95/98/NT. Nucleic Acids Symp Ser 41:95-98

Hardy SM, Carr CM, Hardman M, Steinke D, Corstorphine E, Mah C (2011) Biodiversity and phylogeography of Arctic marine fauna: insights from molecular tools. Mar Biodiv 41:195-210. https:// doi.org/10.1007/s12526-010-0056-x

Haydar D, Hoarau G, Olsen JL, Stam WT, Wolff WJ (2011) Introduced or glacial relict? Phylogeography of the cryptogenic tunicate Molgula manhattensis (Ascidiacea, Pleurogona). Divers Distrib 17:68-80. https://doi.org/10.1111/j.1472-4642.2010.00718.x

Hillis DM, Moritz C, Mable BK (1996) Molecular systematic, 2nd edn. Sinauer Associates, Sunderland

Hopkins CCE (2002) Introduced marine organisms in Norwegian waters, including Svalbard. In: Leppäkoski E, Gollasch S, Olenin $\mathrm{S}$ (eds) Invasive aquatic species of Europe. Distribution, impacts and management. Springer, Dordrecht, pp 240-252

Hou Z, Fu J, Li S (2007) A molecular phylogeny of the genus Gammarus (Crustacea: Amphipoda) based on mitochondrial and nuclear gene sequences. Mol Phylogenet Evol 2:596-611. https ://doi.org/10.1016/j.ympev.2007.06.006

Hupało K, Mamos T, Wrzesińska W, Grabowski M (2018) First endemic freshwater Gammarus from Crete and its evolutionary history - an integrative taxonomy approach. PeerJ 6:e4457. https ://doi.org/10.7717/peerj.4457

Ikko NV, Lyubina OS (2010) Distribution of the genus Gammarus (Crustacea, Amphipoda) along the coast of Arctic fjords as an indicator of prevailing environmental conditions. Doklady Biol Sci 431:149-151

Ingólfsson A (1992) The origin of the rocky shore fauna of Iceland and the Canadian maritimes. J Biogeogr 19(6):705-712

Ingólfsson A (2009) A marine refugium in Iceland during the last glacial maximum: fact or fiction? Zool Scr 38:663-665. https://doi. org/10.1111/j.1463-6409.2009.00405.x

IPCC (2014) Climate Change 2014: synthesis report. In: Core Writing Team, Pachauri RK, Meyer LA (eds) Contribution of Working Groups I, II and III to the fifth assessment report of the Intergovernmental Panel on Climate Change. IPCC, Geneva

Kettle AJ, Morales-Muñiz A, Roselló-Izquierdo E, Heinrich D, Vøllestad LA (2011) Refugia of marine fish in the northeast Atlantic during the last glacial maximum: concordant assessment from archaeozoology and palaeotemperature reconstructions. Clim Past 7:181-201. https://doi.org/10.5194/cp-7-181-2011

Klütsch CFC, Manseau M, Anderson M, Sinkins P, Wilson PJ (2017) Evolutionary reconstruction supports the presence of a Pleistocene Arctic refugium for a large mammal species. J Biogeogr 44(12):2729-2739. https://doi.org/10.1111/jbi.13090

Krebes L, Blank M, Bastrop R (2011) Phylogeography, historical demography and postglacial colonization routes of two amphiAtlantic distributed amphipods. Syst Biodivers 9:259-273

Lambeck K, Yokoyama Y, Purcell T (2002) Into and out of the last glacial maximum: sea-level change during Oxygen Isotope Stages 3 and 2. Q Sci Rev 21:343-360

Landvik JY, Bondevik S, Elverhøi A, Fjeldskaar W, Mangerud J, Salvigsen O, Siegert MJ, Svendsen JI, Vorren TO (1998) The last glacial maximum of the Barents Sea and Svalbard area: ice sheet extent and configuration. Q Sci Rev 17:43-75

Landvik JY, Brook EJ, Gualtieri L, Raisbeck G, Salvigsen O, Yiou F (2003) Northwest Svalbard during the last glaciation: ice-free areas existed. Geology 31:905-908

Librado P, Rozas J (2009) DnaSP v5: a software for comprehensive analysis of DNA polymorphism data. Bioinformatics 25(11):1451-1452. https://doi.org/10.1093/bioinformatics/btp187 
Lincoln RJ (1979) British Marine Amphipoda. British Museum (Natural History), London

Maggs C, Castilho R, Foltz D, Henzler C, Jolly M, Kelly J, Olsen J, Perez K, Stam W, Vainola R, Viard F, Wares J (2008) Evaluating signatures of glacial refugia for North Atlantic benthic marine taxa. Ecology 89(11):S108-S122

Mamos T, Wattier R, Burzyński A, Grabowski M (2016) The legacy of a vanished sea: a high level of diversification within a European, freshwater amphipod species complex driven by $15 \mathrm{My}$ of Paratethys regression. Mol Ecol 25:795-810. https://doi. org/10.1111/mec.13499

Mangerud J, Dokken TM, Hebbeln D, Heggen B, Ingólfsson O, Landvik JY, Mejdahl V, Svendsen JI, Vorren TO (1998) Fluctuations of the Svalbard-Barents Sea Ice Sheet during the last 150,000 years. Q Sci Rev 17:11-42

Neukermans G, Oziel L, Babin M (2018) Increased intrusion of warming Atlantic water leads to rapid expansion of temperate phytoplankton in the Arctic. Glob Chang Biol 24:2545-2553. https://doi.org/10.1111/gcb.14075

Nilsen F, Cottier F, Skogseth R, Mattsson S (2008) Fjord-shelf exchanges controlled by ice and brine production: the interannual variation of Atlantic Water in Isfjorden, Svalbard. Cont Shelf Res 28:1838-1853

Piechura J, Beszczyńska-Moller A, Osiński R (2001) Volume, heat and salt transport by the West Spitsbergen Current. Polar Res 20:233-240

Polyakov IV, Pnyushkov AV, Alkire MB, Ashik IM, Baumann TM, Carmack EC, Goszczko I, Guthrie J, Ivanov VV, Kanzow T, Krishfield R, Kwok R, Sundfjord A, Morison J, Rember R, Yulin A (2017) Greater role for Atlantic inflows on sea-ice loss in the Eurasian Basin of the Arctic Ocean. Science 356:285291. https://doi.org/10.1126/science.aai8204

Puillandre N, Lambert A, Brouillet S, Achaz G (2012) ABGD, Automatic Barcode Gap Discovery for primary species delimitation. Mol Ecol 21:1864-1877. https://doi.org/10.1111/j.1365294X.2011.05239.x

Radulovici AE (2012) A tale of two biodiversity levels inferred from DNA barcoding of selected North Atlantic crustaceans. Ph.D. thesis. University of Quebec

Rambaut A, Suchard MA, Xie D, Drummond AJ (2014) Tracer v1.6. http://beast.bio.ed.ac.uk/Tracer. Accessed 18 February 2016

Ratnasingham S, Hebert PDN (2007) BOLD: the barcode of life data system (www.barcodinglife.org). Mol Ecol Notes 7:355-364. https://doi.org/10.1111/j.1471-8286.2007.01678.x

Ratnasingham S, Hebert PDN (2013) A DNA-based registry for all animal species: the Barcode Index Number (BIN) system. PLoS ONE 8(8):e66213. https://doi.org/10.1371/journal.pone.00662 13

Raymond M, Rousset F (1995) An exact test for population differentiation. Evolution 49(6):1280-1283. https://doi.org/10.2307/24104 54

Rewicz T, Wattier R, Grabowski M, Rigaud T, Bącela-Spychalska K (2015) Out of the Black Sea: phylogeography of the invasive killer shrimp Dikerogammarus villosus across Europe. PLoS ONE 10:e0118121. https://doi.org/10.1371/journal.pone.0118121

Schytt V, Hoppe G, Blake W Jr, Grosswald MG (1968) The extent of the Würm glaciation in the European Arctic: a preliminary report about the Stockholm University Svalbard Expedition 1966. Int Assoc Sci Hydrol Publ 79:207-216

Seutin G, White BN, Boag PT (1991) Preservation of Avian blood and tissue samples for DNA analyses. Can J Zool 69:82-90

Steele VJ, Steele DH (1970) The biology of Gammarus (Crustacea, Amphipoda) in the northwestern Atlantic. II. Gammarus setosus Dementieva. Can J Zool 48:659-671
Steele VJ, Steele DH (1972) The biology of Gammarus (Crustacea, Amphipoda) in the northwestern Atlantic. V. Gammarus oceanicus Segerstråle. Can J Zool 50:801-813

Steele DH, Steele VJ (1974) The biology of Gammarus (Crustacea, Amphipoda) in the northwestern Atlantic. VIII. Geographic distribution of the northern species. Can J Zool 52:1115-1120

Steele DH, Steele VJ (1975) The biology of Gammarus (Crustacea, Amphipoda) in the northwestern Atlantic. XI. Comparison and discussion. Can J Zool 53:1116-1126

Stempniewicz L, Błachowiak-Samołyk K, Węsławski JM (2007) Impact of climate change on zooplankton communities, seabird populations and arctic terrestrial ecosystem-a scenario. Deep-Sea Res II 54:2934-2945

Stephensen K (1940) The Amphipoda of N. Norway and Spitsbergen with adjacent waters. Tromso Museum Skrifter, Tromso

Stroeve JC, Serreze MC, Holland MM, Kay JE, Malanik J, Barrett AP (2012) The Arctic's rapidly shrinking sea ice cover: a research synthesis. Clim Change 110:1005-1027. https://doi. org/10.1007/s10584-011-0101-1

Svendsen H, Beszczyńska-Moller A, Hagen JO, Lefauconnier B, Tverberg V, Gerland S, Orbaek JB, Bischof K, Papucci C, Zajaczkowski M, Azzolini R, Bruland O, Wiencke Ch, Winther JG, Dallmann W (2002) The physical environment of Kongsfjorden-Krossfjorden, an Arctic fjord system in Svalbard. Polar Res 21:133-166

Tajima F (1989) Statistical method for testing the neutral mutation hypothesis by DNA polymorphism. Genetics 123(3):585-595

Troitsky L, Punning J-M, Hütt G, Rajamäe R (1979) Pleistocene glaciation chronology of Spitsbergen. Boreas 8:401-407

Tzvetkova N (1975) Pribrejnye gammaridy severnyh i dal'nevostochnyh morei SSSR i sopredel'nyh vod. Leningrad University, Leningrad

Vihtakari M, Welcker J, Moe B, Chastel O, Tartu S, Hop H, Bech C, Descamps S, Gabrielsen GW (2018) Black-legged kittiwakes as messengers of Atlantification in the Arctic. Sci Rep 8:1178. https://doi.org/10.1038/s41598-017-19118-8

Walczowski W, Piechura J, Goszczko I, Wieczorek P (2012) Changes of the Atlantic Water properties: an important factor of the European Arctic marine climate. ICES J Mar Sci 69:864-869

Waltari E, Hickerson M (2013) Late Pleistocene species distribution modelling of North Atlantic intertidal invertebrates. J Biogeogr 40:249-260. https://doi.org/10.1111/j.1365-2699.2012.02782.x

Ware C, Berge J, Sundet JH, Kirkpatrick JB, Coutts ADM, Jelmert A, Olsen SM, Floerl O, Wisz MS, Alsos IG (2013) Climate change, non-indigenous species and shipping: assessing the risk of species introduction to a high-Arctic archipelago. Divers Distrib 20(1):10-19. https://doi.org/10.1111/ddi.12117

Wares JP, Cunningham CW (2001) Phylogeography and historical ecology of the North Atlantic intertidal. Evolution 55(12):2455-2469

Werle E, Schneider C, Renner M, Völker M, Fiehn W (1994) Convenient single-step, one tube purification of PCR products for direct sequencing. Nucleic Acids Res 22(22):4354-4355

Węsławski JM (1983) Observations on the coastal Amphipoda of the Hornsund Fiord (South West Spitsbergen). Pol Arch Hydrobiol 30(3):199-207

Węsławski JM (1991) Malacostraca. In: Klekowski RZ, Węsławski JM (eds) Atlas of the marine fauna of Southern Spitsbergen. Institute of Ecology, Institute Oceanology, Polish Academy of Sciences, Gdańsk, pp 118-357

Węsławski JM (1994) Gammarus (Crustacea, Amphipoda) from Svalbard and Franz Josef Land. Distribution and density. Sarsia 79:145-150

Węsławski JM, Wiktor J, Zajączkowski M, Swerpel S (1993) Intertidal zone of Svalbard, Macroorganism distribution and biomass. Polar Biol 13:73-79 
Węsławski JM, Kwaśniewski S, Stempniewicz L (2009) Warming in the Arctic May result in the negative effects of increased biodiversity. Polarforschung 78(3):105-108

Węsławski JM, Wiktor J, Kotwicki L (2010) Increase in biodiversity in the arctic rocky littoral, Sorkappland, Svalbard, after 20 years of climate warming. Mar Biodivers 40:123-130

Węsławski JM, Dragańska-Deja K, Legeżyńska J, Walczowski W (2018) Range extension of a boreal amphipod Gammarus oceanicus in the warming Arctic. Ecol Evol 8(15):7624-7632. https ://doi.org/10.1002/ece3.4281

Weydmann A, Carstensen J, Goszczko I, Dmoch K, Olszewska A, Kwaśniewski S (2014) Shift towards the dominance of boreal species in the Arctic: inter-annual and spatial zooplankton variability in the West Spitsbergen Current. Mar Ecol Prog Ser 501:41-52
Weydmann A, Przyłucka A, Lubośny M, Walczyńska KS, Serrão EA, Pearson GA, Burzyński A (2018) Postglacial expansion of the Arctic keystone copepod Calanus glacialis. Mar Biodivers 48:1027-1035. https://doi.org/10.1007/s12526-017-0774-4

Whiteley NM, Rastrick SPS, Lunt DH, Rock J (2011) Latitudinal variations in the physiology of marine gammarid amphipods. J Exp Mar Biol Ecol 400:70-77. https://doi.org/10.1016/j.jembe .2011 .02 .027

Publisher's Note Springer Nature remains neutral with regard to jurisdictional claims in published maps and institutional affiliations. 